\title{
INDUSTRIAL STRATEGY AND LOCAL ECONOMIC DEVELOPMENT: THE CASE OF THE FOUNDRY INDUSTRY IN EkURHUleni Metro ${ }^{1}$
}

\author{
T Phele, S Roberts and I Steuart
}

School of Economic and Business Sciences, University of the Witwatersrand

\begin{abstract}
This article explores the challenges for the development of manufacturing through a case study of the foundry industry in Ekurhuleni Metropolitan Municipality. Ekurhuleni Metro covers the largest concentration in South Africa, but the industry's performance has been poor over the past decade. The findings reported here highlight the need to understand firm decisions around investment, technology and skills, and the role of local economic linkages in this regard. The differing performance of foundries strongly supports the need to develop concrete action plans and effective institutions at local level to support the development of local agglomerations.
\end{abstract}

JEL O14, O33

1

\section{Introduction}

A new emphasis has been placed on local economic development in South Africa with all municipalities required to draw up Integrated Development Plans (IDPs). In addition, many of the actions anticipated under the Department of Trade and Industry's Integrated Manufacturing Strategy (DTI, 2002) require implementation at local or regional level (Machaka \& Roberts, 2003). Furthermore, the Department of Science and Technology's Advanced Manufacturing Technology Strategy (NACI, 2003) envisages a range of measures, including the establishment of technology centres and innovation networks which, while national in scope, require concrete actions at a local level. Indeed, while policy is formulated at national level, local government plays a crucial role in the implementation of the national policies, especially in large industrial metropolitan municipalities such as Ekurhuleni. This is distinct from the local economic development policies that local governments formulate on issues such as roads, water and sanitation.
We use a case study of the foundry industry in the area governed by Ekurhuleni Metropolitan Municipality to examine the development of manufacturing firm capabilities and the implications for industry and technology policy. ${ }^{2}$ We assess the industry's performance in light of recent literature addressing agglomeration effects, industrial districts, and the development of local economic competencies and institutions.

The Ekurhuleni Metropolitan Municipality is located in the eastern region of Gauteng Province, by far the largest provincial economy in South Africa. Ekurhuleni is one of six metropolitan municipalities created in major urban concentrations. More importantly, it covers the largest industrial concentration in South Africa and in sub-Saharan Africa. The economy of Ekurhuleni reflects the apartheid legacy of minerals-oriented industrialisation and the growth of an urban labour pool to supply the mines. Ekurhuleni grew on the back of the main concentration of gold mining in the country. This is reflected in the structure of manufacturing. Ekurhuleni accounted for 37 per cent of South African output of machinery and 33 per cent of metal products in 1996, with the major market for each historically being 
mining. ${ }^{3}$ The performance of the Ekurhuleni economy has, however, been very poor in recent years and, with the decline in gold mining, unemployment increased sharply to reach 40 per cent in 2002. ${ }^{4}$ Manufacturing in Ekurhuleni recorded an average annual growth of valueadded of just 0.4 per cent between 1997 and 2002 (much lower than the national manufacturing annual growth of 2.3 per cent). Regeneration of the industrial base is thus crucial to addressing unemployment and poverty in the region.

\subsection{Manufacturing development and production capabilities}

Despite international trends to liberalisation and increased international flows of goods and capital, industrial activity remains highly concentrated in local regions or districts (Helmsing, 2001). Different explanatory frameworks have been developed, with differing implications for the role of local government. The new economic geography associated with Krugman emphasises externalities, associated with labour markets and skills development, specialist inputs required by firms, and technology spill-overs (Krugman, 1998a \& b).

In contrast, a focus on the organisation of production rather than market failures in exchange underpins frameworks explaining the dynamic of local economic development and the collective development of firm competencies at the local level (Best, 2001; Schmitz, 1995). Local economic development can be approached utilising a framework of inter-firm relationships, productive and technological capabilities, and the role of institutions. In this approach, not only are there processes of cumulative causation driving the returns to firms from location decisions, but it is important to understand the position of firms in terms of their vertical and horizontal relationships and the role of large firms in governing value chains (Kaplinsky, 2000). This view emphasises that the orientation of firms and their relationships with government are influenced by the historical development of capitalism in a country (Chandler et al., 1997).
Technological capabilities are a central element of firms' overall capabilities (Lall, 2003). However, there are widespread and intrinsic features related to technological capabilities, which means it takes time and effort to learn to use technologies, and that private firms will inherently under-invest in the related activities to build technological capabilities (Lall \& Teubal, 1998; Lall, 1994). Firms deal with the demands of technological changes by developing organisational and managerial routines. Market failures are pervasive and learning and technical change involve ongoing incremental and pathdependent processes. This corresponds with a wide range of studies examining detailed processes of technological change and economic development at the institutional level (for a review see Dosi et al., 1994).

This approach has drawn from contributions in economic history, such as those by Chandler, that have found the types of organisation required to successfully exploit technologies to be a major part of explaining countries' different industrial growth performance (Chandler, 1990; Chandler et al. 1997). Amsden has particularly highlighted the importance of organisational characteristics in late industrialisers where the main challenge has to do with adopting and adapting technologies from industrialised nations (Amsden, 1997).

The potential gains from shared learning, a wide skills pool, and sharing of appropriate institutions supporting research, training and development are important in explaining why - despite globalisation - production is increasingly concentrated in specific locations (Helmsing, 2001). These factors mean that there is a strong path dependency driving agglomeration effects. Locations and countries that were first-movers derive an initial advantage that is compounded over time. For late industrialisers the clear implication is that co-ordinated and purposive action is very important in the development of more sophisticated industrial activities (Lall, 2003). Analyses of the East Asian experience of industrialisation have highlighted the importance of co-ordination across $\mathrm{R} \& \mathrm{D}$, 
investment, training, and product development activities within selected sectors (see, for example, Lall, 1994; Lall and Teubal, 1998).

\subsection{Industrial and technology policy in South Africa}

South Africa is a very interesting example of a late industrialiser, as relatively advanced capabilities were developed in areas which tied into the apartheid government's strategic priorities, such as defence and liquid fuels, and the particular demands of mining. Part of this orientation was a "science-push" approach to research, through organisations such as the CSIR and Denel ${ }^{-5}$ After the first democratic elections in 1994, very different priorities of the ANC government led to a wholesale rethink of industrial and technology policy. Trade liberalisation led to far-reaching industrial restructuring. Funding for the old research priorities was reduced, and a new technology mission was elucidated in the National Research and Development Strategy (DST, 2002).

By comparison, current industrial and technology policy frameworks aim to encourage downstream value-addition and employment creation. The Advanced Manufacturing Technology Strategy (AMTS) and the Integrated Manufacturing Strategy (IMS) complement each other. These strategies emphasise the need to develop production capabilities, for firms and public institutions to work together effectively, and for technologies to be the foundation for growth of output and employment. Many of these areas require action at local level.

The IMS places increased emphasis on valueaddition at the downstream levels and the strengthening of vertical and horizontal linkages. The strategy identifies a range of broad issues, such as pricing of inputs, improvement of skills, and technological capabilities, to be taken forward through specific policy measures. The AMTS also establishes a framework for government action to support industrial development, specifically in areas relating to research, technology and productive capacities.

\section{2}

\section{Ekurhuleni - The workshop of sub- Saharan Africa}

Industry in Ekurhuleni is concentrated in intermediate products such as machinery and metal products, and consumer goods including food products and consumer chemicals (such as soaps and paints). It does not have a significant proportion of the very capitalintensive upstream industries such as nonferrous metals, basic chemicals and basic iron \& steel. Instead, industry in Ekurhuleni generally uses basic metals and basic chemicals, produced elsewhere in South Africa, as material inputs for higher value-added and more labourintensive manufacturing.

The sectors in which Ekurhuleni is strongest have also been among the hardest hit by the restructuring induced by the liberalisation and the tight macroeconomic policies in place since the mid-1990s (albeit now being relaxed). The largest industry grouping of metals, machinery and appliances experienced a major contraction in activity in 1998 and 1999 (Figure 1). 


\section{Figure 1}

Value-added of manufacturing sub-groupings in Ekurhuleni

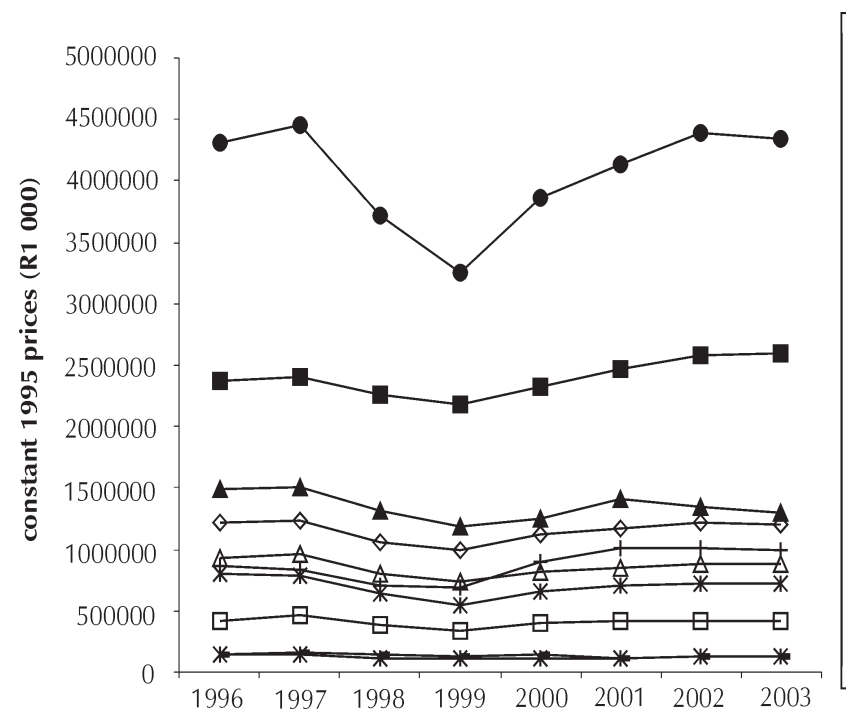

\begin{tabular}{|c|c|}
\hline- & $\begin{array}{l}\text { Food, beverages and } \\
\text { tobacco products }\end{array}$ \\
\hline * & $\begin{array}{l}\text { Textiles, clothing and } \\
\text { leather goods }\end{array}$ \\
\hline$\triangle$ & $\begin{array}{l}\text { Wood and wood } \\
\text { products }\end{array}$ \\
\hline & $\begin{array}{l}\text { Fuel, petroleum, chemical } \\
\text { and rubber products }\end{array}$ \\
\hline$\rightarrow$ & $\begin{array}{l}\text { Other non-metallic } \\
\text { mineral products }\end{array}$ \\
\hline & $\begin{array}{l}\text { Metal products, machinery } \\
\text { and household appliances }\end{array}$ \\
\hline$\square$ & $\begin{array}{l}\text { Electrical machinery } \\
\text { and apparatus }\end{array}$ \\
\hline- & $\begin{array}{l}\text { Electronic, sound/vision, } \\
\text { medical \& other appliances }\end{array}$ \\
\hline+ & Transport equipment \\
\hline$\diamond$ & $\begin{array}{l}\text { Furniture and other items } \\
\text { NEC and recycling }\end{array}$ \\
\hline
\end{tabular}

Source: Global Insight

While there has been a recovery in value-added, there is quite a different picture in terms of employment (Figure 2). After massive job losses in metals, machinery and appliances and in other non-metallic minerals (which includes cement and brick-making), employment levels have only increased marginally in recent years.

Figure 2

Formal employment in manufacturing in Ekurhuleni

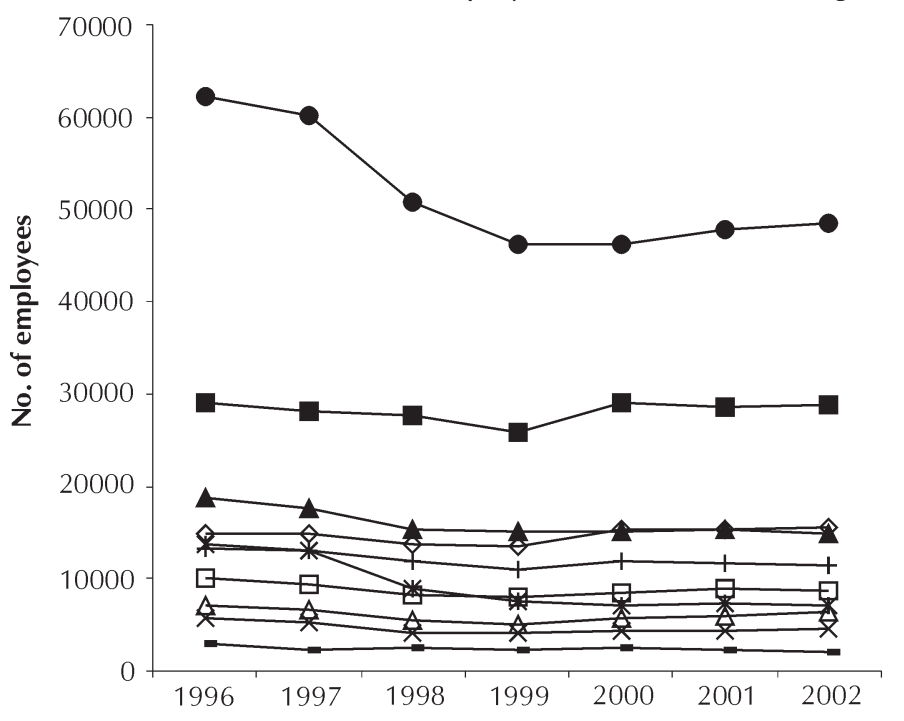
—— Food, beverages and tobacco products
$*$ Textiles, clothing and leather goods
$\multimap$ Wood and wood products
$\rightarrow$ - Fuel, petroleum, chemical and rubber products
* Other non-metallic mineral products
- - Metal products, machinery and household appliances
_- Electrical machinery and apparatus
$\longrightarrow$ Electronic, sound/vision, medical \& other appliances
$\rightarrow$ Transport equipment
_ Furniture and other items NEC and recycling


The performance of the Ekurhuleni economy has reflected the overall patterns of development in the South African economy and the very poor performance of more labour-intensive downstream sectors, and of sectors with higher levels of value-added such as machinery and equipment. ${ }^{6}$ Manufacturers in Ekurhuleni also suffer from the pricing practices of the dominant upstream suppliers of basic chemicals and basic metals, which are located elsewhere (Dobreva \& Madosi, 2004; Masethe \& Roberts, 2003). These firms charge prices at import parity levels for products, even where South African production greatly exceeds demand and there is a large trade surplus.

Liberalisation and increasing international integration have induced changes in firms' competitive orientation. Despite the relatively low level of direct exports by firms in Ekurhuleni, firm survey results reveal that firms responding to increased competition through quality, design and delivery time are performing much better than those that have a narrow price-based orientation. ${ }^{7}$ The emphasis on non-price competitiveness suggests the importance of developing strong local linkages and institutions.

The findings on production costs, investment and training strongly reinforce the fact that firms whose strategies are oriented to non-price factors perform better than firms that base their strategies on cost competitiveness alone. Across all these areas, firms that have upgraded skills, machinery and equipment are reaping gains in terms of higher output growth and employment. Rather than investment being labour replacing, it is strongly associated with employment creation, as firms upgrade capital stock as part of a dynamic growth path. The main motivation for investment was demand expectations, followed by the need to raise efficiency and to improve quality by employing more up-to-date technology.

The findings from the manufacturing survey all point to the need to understand firms' production capabilities, their adoption of improved technologies, and upgrading of skills. These are evidently central to realising the objectives of national industrial and technology policies. In the context of Ekurhuleni, this is directly relevant to understanding the extent to which the orientation of manufacturing industry shifts from one focused on mining and resourcebased activities to a broader-based growth path. The case study of the foundry industry enables us to explore these issues in much greater depth.

\section{3}

Industrial development and production capabilities: the case of the foundry industry in Ekurhuleni

\subsection{Industry overview}

The South African foundry industry consists of over 200 foundries (including ferrous and nonferrous foundries), generating a combined turnover of R10.3 billion (Viljoen, 2003). The number of firms has shrunk significantly from over 400 at the end of the 1980 s, although new entrants since 2001 have increased numbers once more. The industry produces 500000 tonnes annually and employs over 15000 people. In terms of market share, the foundry industry is dominated by a small number of large groups and individual companies. Eight companies account for more than 60 per cent of tonnes cast and more than 70 per cent of total employment.

The South African foundry industry mainly serves the mining, automotive, and general engineering sectors. Automotive components account for approximately 40 to 50 per cent of the industry's total production, followed closely by mining. Of the approximately 500000 tonnes of metal cast, 80 per cent is ferrous and 20 per cent non-ferrous. With respect to non-ferrous production, however, approximately 85 per cent of all aluminium castings produced in South Africa are supplied to the automotive industry (Viljoen, 2003). The aluminium foundry industry has shown consistent growth since 1992, attributed largely to the Department of Trade and Industry's Motor Industry Development Plan (MIDP).

Geographically, more than half of all the foundries in South Africa are located in Gauteng. In turn, more than 65 per cent of all foundries operating in Gauteng are situated in 
Ekurhuleni, due largely to historical demand from a concentration of firms in the mining, metals and machinery, and engineering sectors. The Western Cape, Eastern Cape and KwaZuluNatal all have significant foundry industries, but these are small relative to Gauteng.

The South African foundry industry has undergone a significant amount of restructuring and consolidation over the past 10 to 15 years. The gradual liberalisation of the South African manufacturing sector since the early 1990s, global improvements in casting technology and the quality of castings, and the ability of transnational corporations to source castings from anywhere in the world, have all heightened competitive pressures in the domestic foundry industry.

The changing patterns of capabilities, with the increased importance of the auto sector and the historical importance of mining, are reflected in the trade performance of the industry. The only two product groupings with consistent trade surpluses since 1995 are "grinding balls and similar articles" (HS732591) and "hydraulic turbines, water wheels and regulators parts" (HS8410) associated with mining and with infrastructure respectively. However, by 2003 auto components accounted for the largest share of exports. "Parts of engines" accounted for 41 per cent of exports, followed by "spark-ignition reciprocating or rotary internal combustion piston engines" at 30 per cent. These product groupings have recorded huge improvements in their net trade performance on the back of large increases in exports.

The main production technologies are sand casting, die casting and investment casting. Of these, sand casting is by far the most widely used in South Africa. It is also less technologically advanced. However, there is a wide spectrum of technological sophistication within sand casting.

Now that the process of liberalisation is broadly complete, the key challenge is to create an enabling environment in which to enhance the competitiveness of firms. The importance of linkages and interdependencies cannot be overstated in an industry that supplies critical intermediate inputs to sectors prioritised by the
AMTS and IMS on which future growth in manufacturing is largely predicated. It is crucial that initiatives to provide an enabling environment for the improved competitiveness of the South African foundry industry are centred on strengthening linkages and improving levels of intra-industry coordination.

\subsection{Firm performance and competitiveness in Ekurhuleni}

This section examines the main factors underlying the performance of the industry, drawing on a survey and interviews of foundries situated in the Ekurhuleni region. The survey, which was sent to all the registered foundries operating within the Ekurhuleni municipal area, focused on technological capabilities and skills development and training in the foundry industry. The interviews concentrated on the institutional arrangements underpinning the industry. Twenty-five foundries responded to the survey, representing a response rate of 34 per cent.

\subsubsection{Overview}

South African foundries are in general locally owned and independent ( 76 per cent of the firms surveyed). In total, the firms surveyed employed 3411 employees in 2003. Small firms represent the largest number, at 44 per cent of the respondents (Table 1), but only accounted for 9 per cent of employment in 2003.

Table 1

Firm size distribution

\begin{tabular}{|l|c|}
\hline $\begin{array}{l}\text { Firm size (by number } \\
\text { of employees) }\end{array}$ & Number of firms \\
\hline Micro $(1-5)$ & 1 \\
\hline Small $(6-49)$ & 11 \\
\hline Medium $(50-250)$ & 6 \\
\hline Large $(>250)$ & 7 \\
\hline
\end{tabular}

Firm performance reflects the recovery in the industry in the past two to three years. Of all the firms surveyed, employment grew at an average annual rate of 3.5 per cent between 2001 and 2003. The majority of firms (68 per cent) reported employment growth, while 24 per cent 
reported negative growth, and 8 per cent reported no change. In addition, in each year from 2001 to 2003 more than half the responding firms recorded high turnover growth (turnover growth in excess of 10 per cent). Firms that reported positive employment growth also reported high growth in turnover.

There are a number of reasons for the relatively good performance of firms. First, it suggests the emergence of a dynamic industry grouping after almost a decade of decline in the industry (confirmed in interviews). Second, the timing of the survey meant it captured improved performance following the rand's depreciation at the end of 2001. Third, it also possibly reflects the greater likelihood of better-performing firms responding to the survey.

\subsubsection{Main markets}

The majority of firms surveyed supply the mining, machinery and equipment, and motor vehicles and transport sectors (Figure 3 ). The findings reflected in Figure 3 differ somewhat from national data in that mining is relatively more important in Ekurhuleni. Sixty-eight per cent of foundries in Ekurhuleni supply the mining sector (exclusively or in addition to other sectors). Nevertheless, the automotive sector has become a significant contributor to the overall output growth in castings in Ekurhuleni, due to the deepening of input linkages encouraged by the evolution of the MIDP.

Figure 3

Main markets

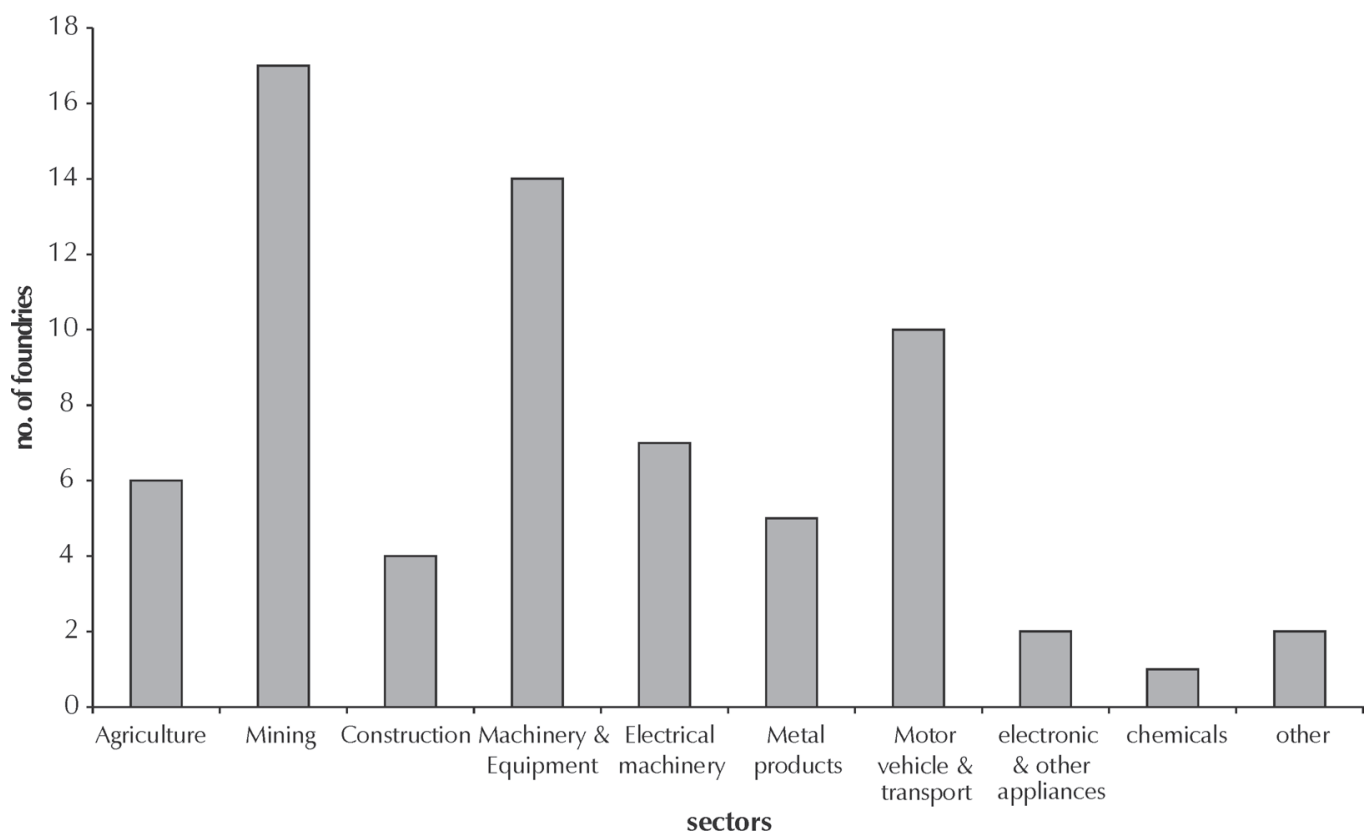

There are clear differences in the demand trends between different markets. While overall capacity utilisation is low with the majority of foundries surveyed running only a single shift per day, firms supplying the auto sector have high levels of capacity utilisation. In addition, firms using more capital-intensive production techniques such as investment and die-casting processes also have higher levels of capacity utilisation. Overall, however, the very low levels of capacity utilisation reflected in the single shifts suggest a circle of weak demand and an inability of firms to access new markets.

Most firms surveyed are negligible exporters or are not involved in export activity at all (Figure 4). ${ }^{9}$ Indeed, only four firms export more than 20 per cent of their sales. Interviews revealed that integration with international 
markets is, however, very important. Foundries are increasingly indirect exporters as their cast components are embodied in products assembled locally for international markets. Thus, direct export orientation has not impacted on firm behaviour as much as firms becoming part of international production networks. In line with the literature discussed above, building local linkages is therefore very important. The most obvious are those linkages found in the auto sector, where improved links with international assemblers with operations in South Africa have supported upgrading of firm capabilities. Similar dynamics were, however, also present in firms selling into machinery and equipment manufacturers who compete in international markets. This suggests that export growth is part and parcel of a dynamic growth process of building capabilities based on linkages and relationships developed locally.

Figure 4

Exports as per centage of turnover

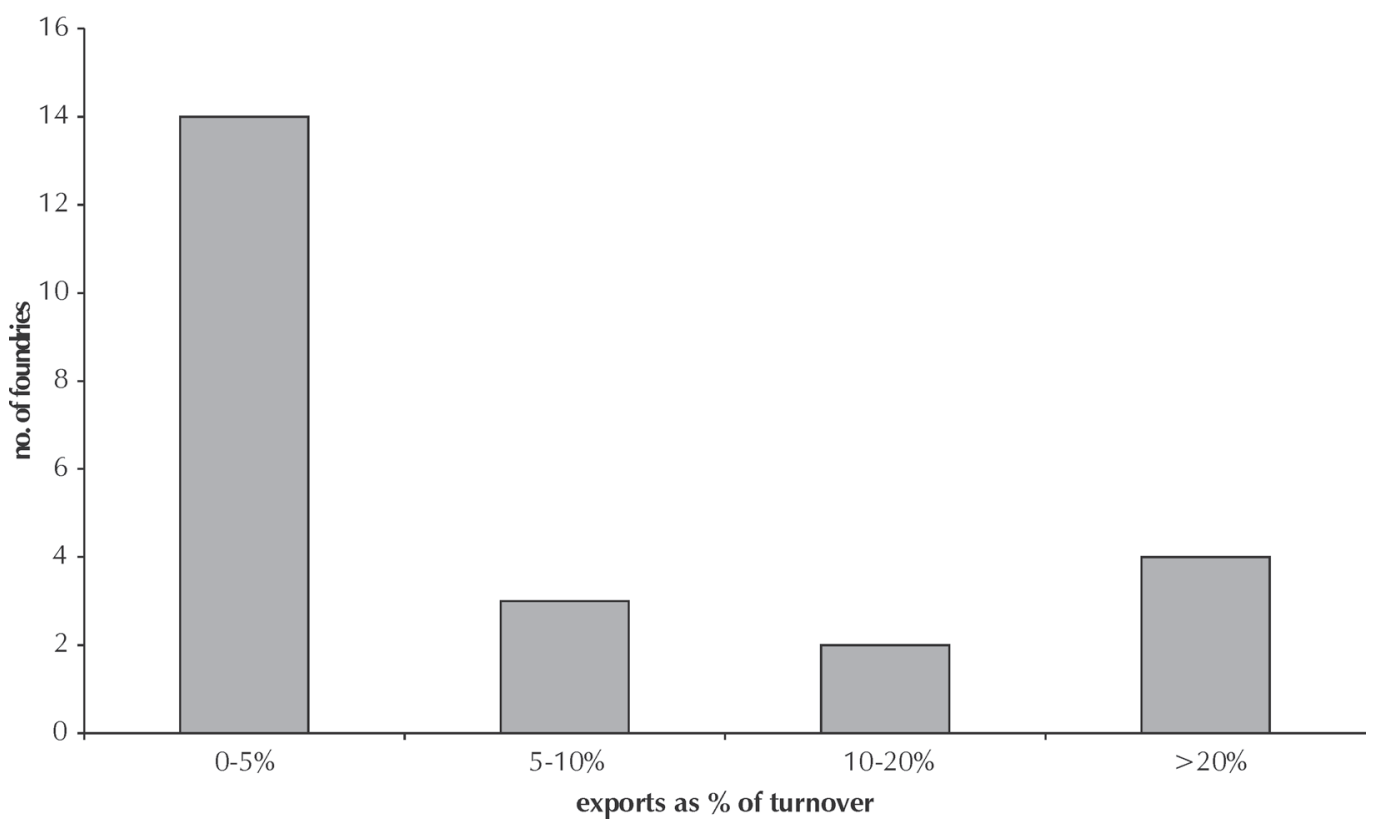

There are significant regional variations in the export orientation of firms. In the Western Cape firms are either negligible exporters (less than five per cent of turnover) or are wholly export oriented (in excess of 90 per cent of turnover). ${ }^{10}$ This is in stark contrast to firms in Gauteng where there is a stronger orientation towards domestic markets (that is, where direct exports typically do not account for more than five per cent of turnover). While transport costs are significantly lower for firms in the Western Cape, export orientation is largely a function of firm strategy and the ability of firms to identify and exploit niche markets (Bertrand et al., 2004).

\subsubsection{Technology and productive capabilities}

The majority of firms tend to specialise in a particular casting process (sand, die or investment casting), with only 16 per cent of firms surveyed using a combination of casting techniques (Table 2). These findings were supported by the follow-up interviews, which revealed a clear trend towards increased specialisation, concentration on core activities, and the outsourcing of non-core functions.

Sixty-eight per cent of firms surveyed use sand casting techniques (of which 76 per cent specialise in sand casting alone), while only two firms surveyed specialise in investment casting (only six foundries in the whole of South Africa use the investment casting process). 
Table 2

Type of casting process ${ }^{11}$

\begin{tabular}{|l|c|}
\hline Method & Number of firms \\
\hline Sand & 17 \\
\hline Die casting & 9 \\
\hline Investment & 2 \\
\hline
\end{tabular}

While two-thirds of firms reported making technological improvements since 2000, these were generally of an incremental nature related to ongoing product development. Approximately one-third of the improvements were reported as radical (substantial shifts in product lines, the development of entirely new goods, or major changes to the production process). Radical improvements tend to be made to the production process rather than the product itself, which ultimately must conform to the specifications of the customer. The firm may suggest changes to the product as part of the process of customer interaction, but these changes are usually not radical.
The importance of firm capabilities and the predominance of incremental product development are emphasised by the survey responses that indicate that the main source of technological improvements is in-house (Figure 5). Moreover, the majority of improvements to casting products or processes, whether in-house, from suppliers, owners or licences, were derived from domestic sources. Of the firms that reported in-house development as the primary source of technological improvements, 69 per cent indicated that it was performed on an on-going basis and 31 per cent indicated that it was performed on an ad hoc basis. All the firms surveyed specialising in either die or investment casting processes have introduced technologically improved casting products or made improvements to the casting processes since 2000 . In contrast, only 38 per cent of all firms using sand casting processes have made improvements to their products and/ or processes over the same period.

\section{Figure 5}

Sources of technological improvements to products and/or processes

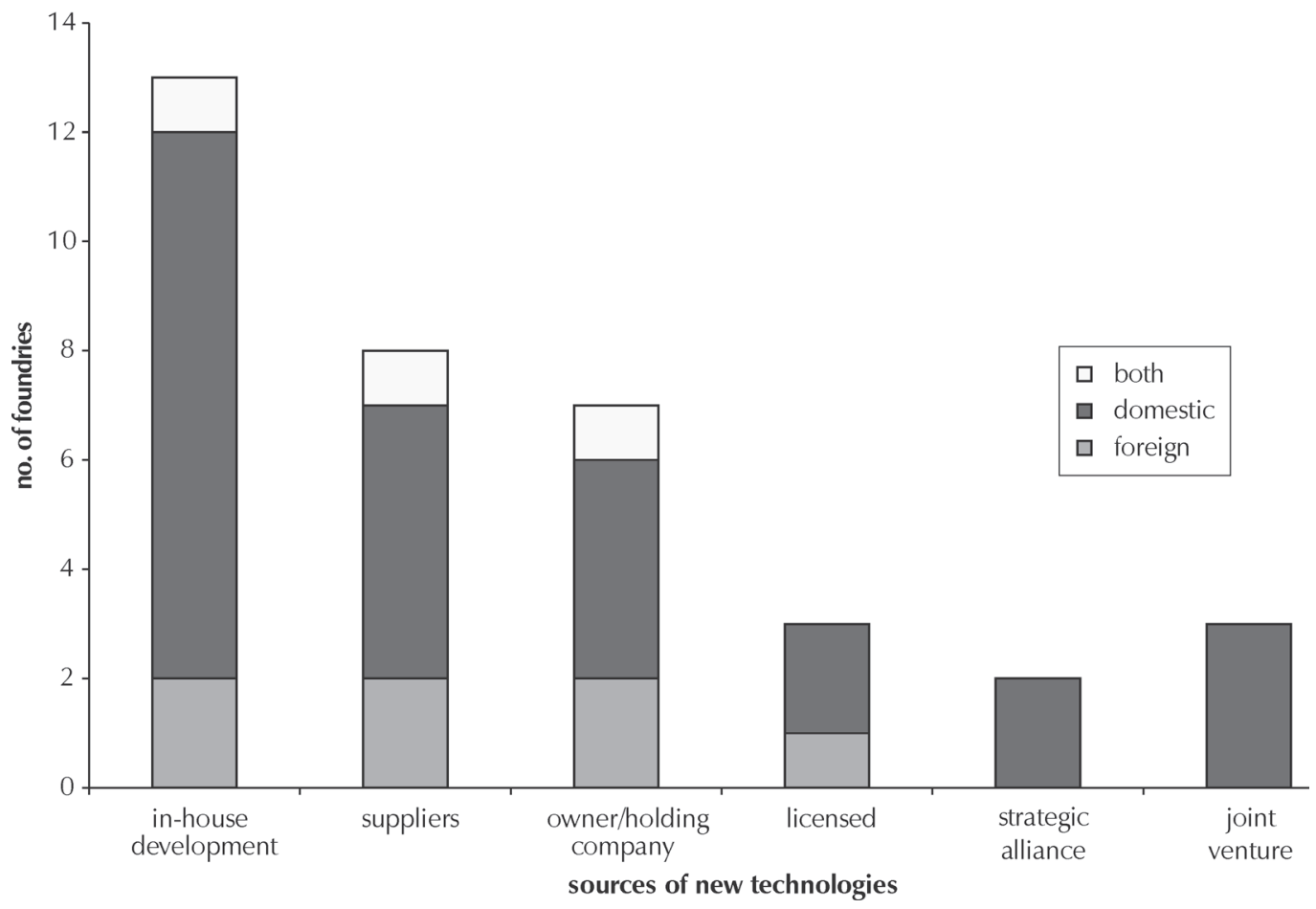


In terms of ownership, the majority of firms with significant foreign ownership specialise either in investment casting or die casting. These firms tend to be more technologically dynamic and significantly more proactive in acquiring new technology than firms involved in sand casting. Foreign ownership, however, should not be viewed as a necessary condition for technological dynamism since there are very dynamic, locally-owned firms across the range of casting techniques. While ownership per se does not differentiate dynamic firms from less dynamic firms, a number of firms that reported making improvements to products and/or processes either have well-established links with foreign organisations (for example, Casting Technology International in the UK, or the American Foundry Society), or are producing castings or using specific casting processes under licence from companies overseas. In these cases, major research and development (R\&D) takes place abroad. The licensee therefore benefits from a significant amount of informationsharing and technical support, allowing it to focus on incremental innovation in products and processes through well-established channels of customer and supplier interaction.

In terms of technological dynamism and the extent to which firms specialising in different processes are able to develop their capabilities, the sector(s) to which firms supply may also be important. Although firms indicated in-house development as the main source of technological improvements, a number of respondents in the interviews indicated that customer interaction was itself a critical component of technological improvements made in-house. In interviews it was evident that firms supplying the automotive sector have clearly benefited from positive externalities generated by the MIDP and have developed their capabilities on the back of the programme's success.

Institutions do not currently play an important role in supporting firms' techno- logical capabilities. No less than 57 per cent of firms surveyed ranked universities/other tertiary institutions, industry associations, and science councils as weak or unimportant sources of information in their innovative efforts. However, 78 per cent of firms ranked science councils as weak or unimportant sources of information. Clearly, greater coordination between industry, tertiary institutions, science councils and other research organisations is needed in developing local foundry capabilities.

Firm interviews reinforced the picture of weak local linkages and information flows. Respondents variously stated that firms were suffering from "a lack of intra-industry cooperation", that individual firms "were extremely reticent to engage in collective discussion and deliberation", and that "more structured institutional arrangements [are needed] in order to facilitate the exchange of ideas between smaller foundries". Addressing these weaknesses will require leadership and coordination between the industry, key institutions and different spheres of government. Improving and/or creating platforms for engagement could be an area in which the local government can play a facilitating role.

Unsurprisingly, firms' expenditure on R\&D appears to be positively correlated with technological improvements: of the firms that have made improvements to products and/or processes since 2000 , over 90 per cent recorded positive expenditure on some form of $R \& D$. Firms, however, indicated the following factors as key impediments to their innovative activities in casting products and/or processes (Figure 6):

- financial constraints

- economic risks

- lack of qualified personnel

- lack of familiarity with new casting technology. 


\section{Figure 6}

Impediments to firms' innovative efforts in casting

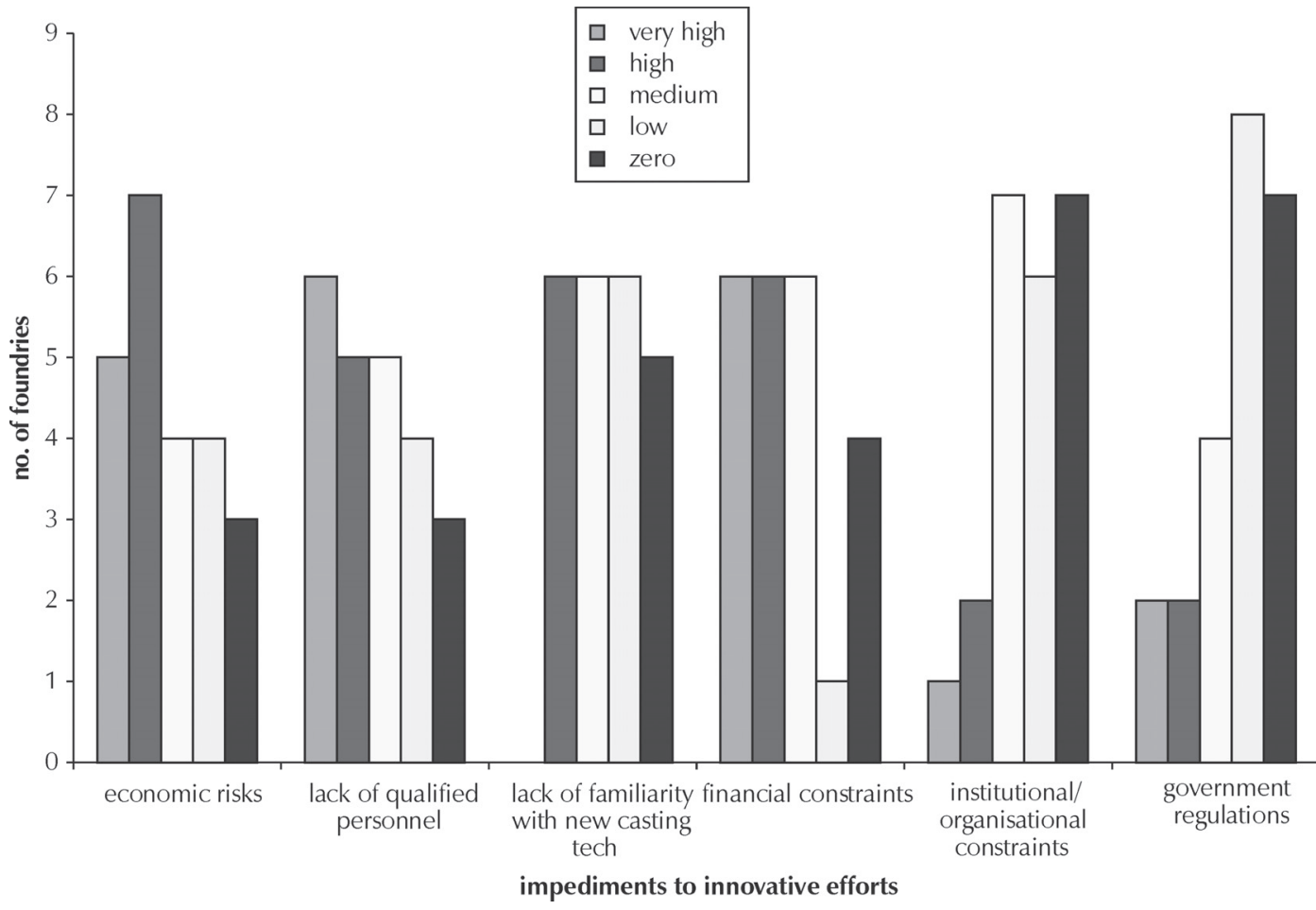

Finally, with respect to testing and certification - an increasingly important component of the casting process -56 per cent of the respondents indicated that they have some testing facilities on-site, although some firms do use laboratories in Ekurhuleni for more sophisticated testing and process certification. Firms without the facilities use the testing facilities of other foundries and/or laboratories in Ekurhuleni. Again, this highlights the gains from agglomeration of industries in a particular region, as intra-industry linkages and joint technology capabilities can develop. The main types of testing and certification services required by firms were identified as follows:

- Radiography

- Tensile testing

- Metal specification

- Chemical composition

- Ultrasonic mechanical testing
- Sand testing and microstructure examination

- Metrology

- Pressure testing and heat treatment

- IEC and SABS quality certification

- Corrosion testing

\subsubsection{Investment}

The majority of firms surveyed indicated that the average age of their casting equipment and machinery is relatively high. Sixty-three per cent of firms reported an average age of machinery of more than 10 years. Twenty-nine per cent reported an average age of between five and 10 years, while only eight per cent of firms reported an average age of less than five years.

Despite this finding, 56 per cent of firms surveyed have made major investments in casting machinery and equipment since 2000 . Most of these firms are in the medium- and large-sized firm categories, suggesting that significant barriers to investment exist for 
smaller firms, which, in light of the independent nature of South African foundries, would not have access to intra-group finance. Importantly, far fewer firms using sand-casting processes made major investments in casting machinery and equipment since 2000 than either die casters or investment casters.

Figure 7

Motivation for investment

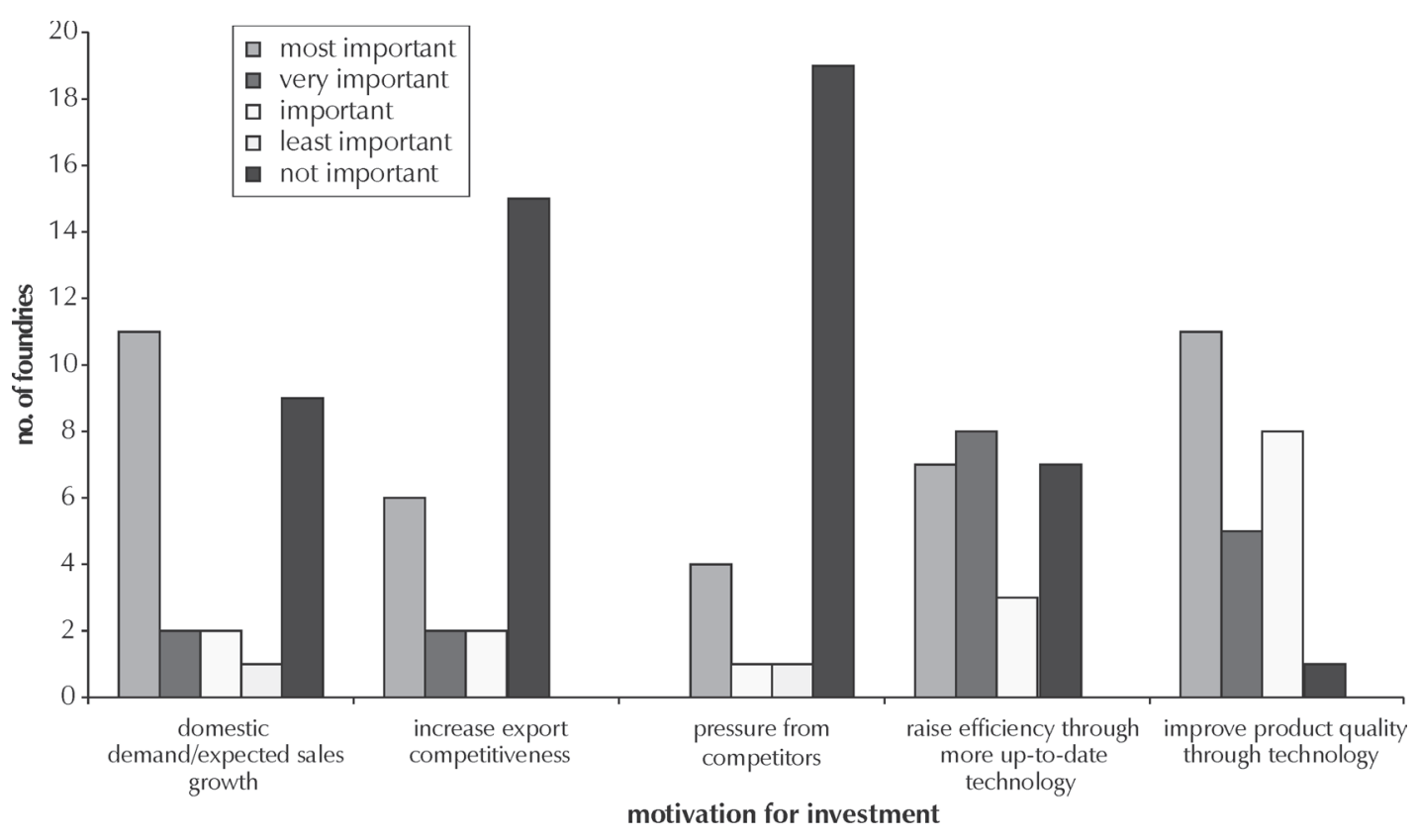

The most important factors motivating firms' investment decisions include the need to improve efficiency and quality, and expected growth in domestic demand (Figure 7). Increased international competitiveness was found to be a relatively insignificant motivational factor, supporting the finding that the vast majority of firms are not (directly) export oriented. Key factors discouraging investment include exchange rate volatility, high interest rates, labour regulations and the exchange rate level. The findings support the conclusion by Viljoen (2003) that the difficulties of financing local investment against a weak currency and high interest rates present a significant challenge to local firms.

There is a clear relationship between upgrading capital stock and better performance. Of the firms that have made significant capital investments in casting technology since 2000, 65 per cent reported an annual growth of more than 10 per cent in turnover in 2003.
Furthermore, while firms across the range of casting processes are embarking on a process of modernisation, it does not appear to be at the expense of labour. Indeed, upgrading capital stock appears to be part of the overall upgrading of capabilities which includes employment growth. Over 71 per cent of firms making major capital investments recorded employment growth in 2003.

\subsubsection{Skills development and training}

Over 70 per cent of firms surveyed reported a level of education below matric as the average level of education of employees on the shop floor. While some shop floor employees have a level of education above matric, there is a significant gap in the level of formal education between them and their colleagues. Only 13 per cent of firms indicated that some form of postmatric training was necessary to ensure an adequate grasp of basic foundry skills. In the interview sessions, the majority of respondents 
indicated that existing levels of education do not impact adversely on productivity, but rather present practical challenges in providing onthe-job training. This is supported by Bertrand et al. (2004), who found that the competitiveness of the foundry industry is affected more by inadequate training than weaknesses in formal education, as such. Another major problem facing the South African foundry industry is the increasingly limited pool of skilled of labour from which to draw. The industry is failing to attract sufficient numbers of graduates and foundries wishing to employ skilled labour are often forced to poach from other firms.

Sixty-five per cent of firms indicated that the average time to train basic foundry skills is greater than three months. While a number of firms have established their own in-house training programmes - in both basic foundry skills and more advanced skills specific to the type of casting process employed - a major problem with these initiatives is that they are not formally accredited.

The importance of an industry-wide, accredited training programme cannot be overstated. Programmes already exist regionally, which could be replicated nationally. Technikon Witwatersrand (now University of Johannesburg) is the main educator on a tertiary level in foundry technology. In addition, the Western Cape Institute of Foundrymen (WCIF) provides accredited training programmes to foundry employees in all aspects of foundry technology. It is very clear that the training programme provided by the WCIF has galvanised local industry and has provided an enabling environment for processes of deliberation, knowledge-sharing and technology transfer between firms. ${ }^{12}$ At present, technikons and other vocational training institutions are the most preferred source of outside training, followed by private training schools and industrial training boards (Figure 8).

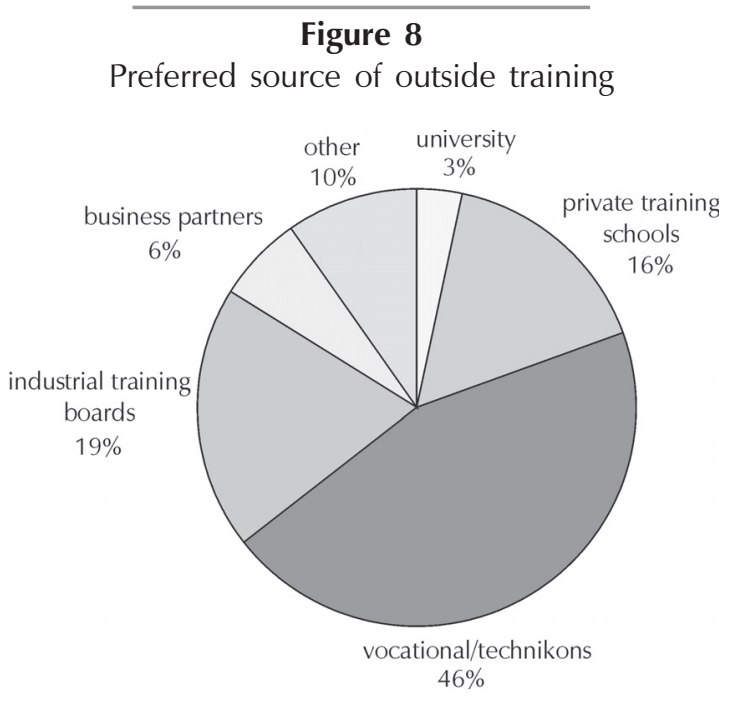

Other challenges that need to be addressed include an increase in the awareness of the importance of on-time delivery amongst shopfloor employees as well as the need to ensure and maintain quality in the production process.

Finally, the seven firms that claimed back the skills development levy are medium or large in size, supporting views expressed by respondents in the interviews that the process of claiming back the skills levy is complicated and laborious, and is a barrier to small firms. There is thus a great potential for accredited training initiatives for small firms as well as for the provision of assistance to small firms in claiming back the skills development levy.

\subsubsection{Government incentives}

The survey reveals that awareness of the various government incentives ${ }^{13}$ available is relatively low and that only a small proportion of firms has used or is making use of the incentive schemes (Figure 9). Only nine foundries, representing 39 per cent of the sample, have used one or more of the incentive schemes. Furthermore, there is a greater tendency among large firms to make use of incentives. Of firms that have used at least one incentive, 67 per cent are large.

The most widely used incentive is the Competitiveness Fund, followed by the Small and Medium Enterprise Development Programme (SMEDP). The MIDP, the 
Technology and Human Resources for Industry Programme (THRIP) and the Innovation Fund are used in the same proportion. While only a small number of firms 'use' the MIDP, in the interviews it was evident that the majority of firms supplying castings to the automotive sector have clearly benefited, albeit indirectly, from the provisions of the MIDP.

Figure 9

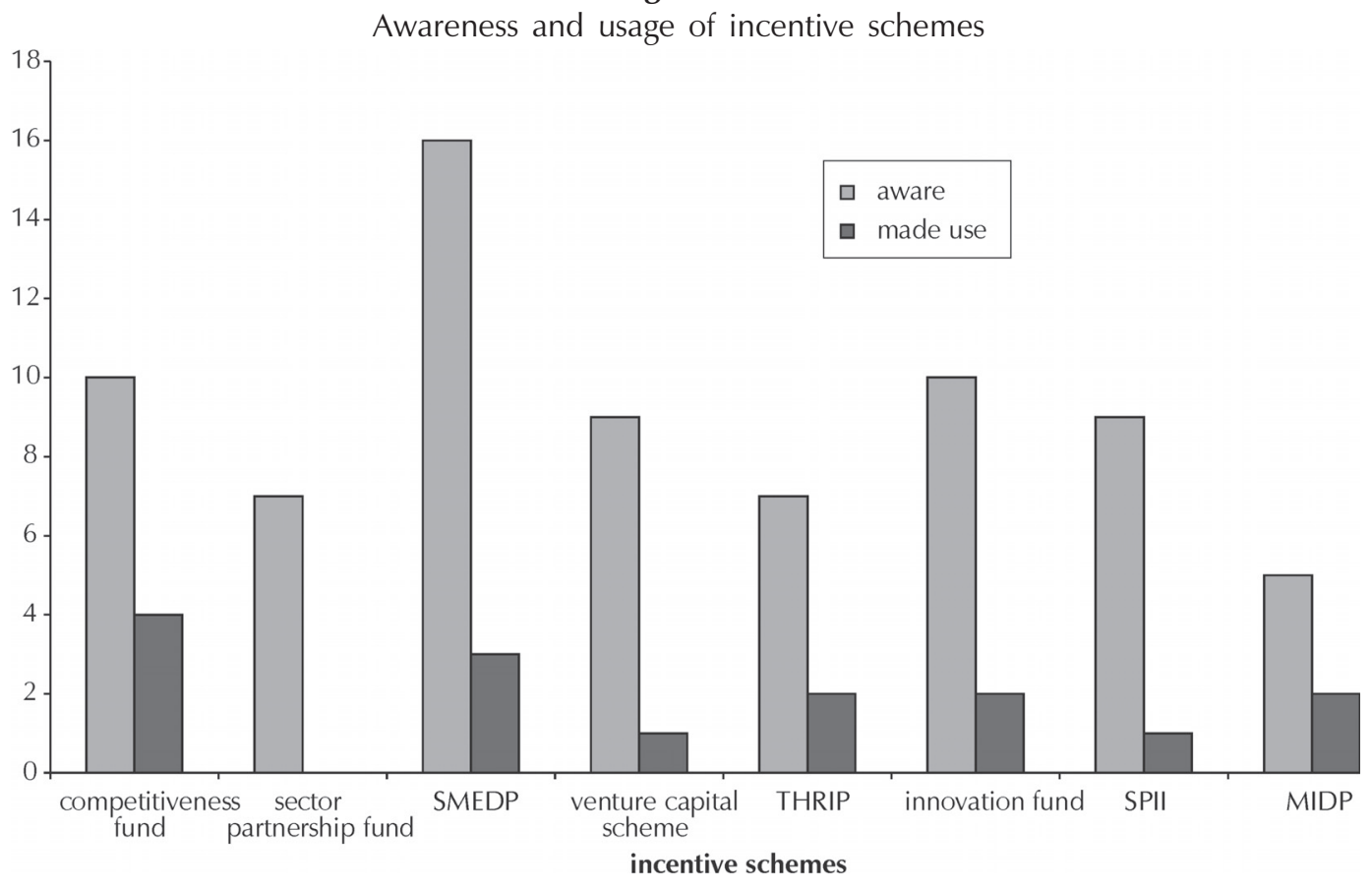

\section{4}

\section{Conclusions}

The development of manufacturing in South Africa's largest industrial concentration in Ekurhuleni is crucial to the success of industrial and technology policies. Manufacturing firms have undergone far-reaching restructuring and have recorded significant reductions in employment. The important question is whether the concentration of activity is now translated into a dynamic industrial agglomeration with sustained improvements in firms' capabilities and technological capacities.

The foundry industry is central to the overall development of local manufacturing capabilities as it provides intermediate inputs to a wide range of other sectors, including machinery and equipment and the auto sector. The findings from the firm survey and in-depth firm interviews highlight the importance of understanding firms' production capabilities. These relate to firms' decisions across product development, investment in new machinery, and training and skills development. Domestic markets and domestic demand are very important factors in this. In particular, the foundry industry demonstrates the gains from the progressive broadening and deepening of local inputs to the auto sector stimulated by the Motor Industry Development Programme. This has provided a foundation for firms to plan investment decisions, upgrade machinery, build technological capabilities and develop skills.

However, while the findings indicate the importance of improved firm capabilities, the industry case study revealed that relationships between industry and tertiary institutions, science councils and other research organisations are chronically weak. There appears to be poor communication and little co-ordination between the industry and these organisations. There is also a striking lack of a 
co-ordinated approach to formal training in basic foundry skills, which the study demonstrates is much more important than the average education level of workers.

The lack of co-ordination between the industry and institutions partly mirrors poor communication between the firms themselves. It does, however, point to a need for a more proactive stance by public institutions in addressing a problem of collective action. The performance of the group of dynamic firms in the industry demonstrates the benefits to be gained from such an approach to support the industry as a whole. In the absence of such an approach it is very doubtful whether the leaps realised by firms supplying the auto industry will somehow be transferred to those supplying machinery and equipment.

An effective strategy for the industry requires information and analysis, followed through with co-ordinated action. Especially for fragmented industries, local government has an important role to play in this process. It can assess the position of industries and represent the needs of the local economies over which they preside to national and provincial government, and national institutions. In addition, local government needs to work with national actors to implement concrete interventions.

This requires capabilities of local government, which appear poorly developed at present. Although municipalities have drawn up Integrated Development Plans (IDPs), as required by law, these plans do not generally address the specific concerns of industrial development. Steps to realise the potential gains from collective action are an important gap between local, provincial and national government. In the absence of such steps, collections of firms will remain unable to realise their potential cluster benefits, and coherent strategies will only emerge for strong and wellorganised industries such as motor vehicles.

International experience of the development of local agglomerations points to the importance of effective co-ordination, together with the implementation of initiatives at the local level, especially around technology, production capabilities and skills development. This is a major challenge for the next decade of South Africa's economic development.

\section{Endnotes}

1 Based on a paper presented at the TIPS/DPRU Forum, Cape Town, September 2004. The useful comments of two referees are acknowledged.

2 The research involved a short survey of firms, followed by 18 in-depth interviews with suppliers, foundries and focus groups to cross-check the analysis.

3 Calculated from data in the latest available manufacturing census, for 1996.

4 On the broad definition. This unemployment rate is significantly higher than for Gauteng (35 per cent) and for major urban areas throughout South Africa.

5 See also Kaplan (1999) for a discussion of the implications of South Africa's historical model of support for R\&D.

${ }^{6}$ The auto sector is an exception in that it has performed well in terms of value-added, but there are no major auto assemblers in Ekurhuleni.

7 Survey of all manufacturing firms in Ekurhuleni in 2003, with 383 responses. See Machaka and Roberts (2004a and b) for full report and analysis of results.

8 This section draws on Viljoen (2003)

9 Figure 4 does not imply that all the firms surveyed are exporting. The first column indicates the number of firms exporting between 0 and 5 per cent of turnover, which includes firms that do not export at all. Furthermore, the survey did not distinguish between direct and indirect exports and hence the data may be understating the number of firms involved in export activity, even if only indirectly.

10 Foundry interviews in the Western Cape, reported in Bertrand et al. (2004).

11 The total reflects firms using more than one process.

12 The WCIF training programme consists of nine modules covering all aspects of foundry technology, including quality control, productivity and production planning, and supervisory management. Each module consists of various chapters and is presented by experienced managers from within the industry itself. The WCIF training programme is accredited with MERSETA and could provide a useful model for a national skills development and training programme in foundry technology. 
13 Government has a number of supply-side measures aimed at attracting investments; encouraging $\mathrm{R} \& \mathrm{D}$; and improving the competitiveness of industries in export markets. The main incentives that the paper refers to are: Competitiveness Fund - a cost-sharing (50:50) grant scheme. It aims to encourage South African companies to become more competitive in local or foreign markets.

Sector Partnership Fund - its objective to support sustainable economic growth and job creation needs of SA by providing financial assistance to partnership of firms in the manufacturing and agro-processing industries and to define and implement collaborative projects related to production and marketing that will enhance their productivity and international competitiveness. SPF supports an eligible partnership of five or more companies in the development and execution of collaborative projects.

Small and Medium Enterprise Development Programme (SMEDP) for Manufacturing - aims to encourage local and foreign capital investment in productive qualifying assets (plant and machinery, land and buildings, commercial vehicles and research and development equipment) up to R100 million so as to create employment and wealth. It is available to enterprises investing in capital in new projects or expanding an existing project, but there are restrictions on the type of legal entity.

Support Programme for Industrial Innovation (SPII) - is a grant of 50 per cent of actual direct cost incurred in pre-competitive development activity up to a maximum of R1.5 million per project. The aim of the grant is to promote the development of local innovative products or processes by private sector companies. All private sector enterprises engaged in manufacturing or an information technology related project.

Technology and Human Resources for Industry Programme (THRIP) - aims to improve the competitiveness of the South African industry by supporting scientific research, technological development and technology diffusion. The scheme is available to all companies that collaborate with educational institutions, which involve the training of students. THRIP contributes between 33 per cent and 50 per cent of the funds invested by a company in research projects.

Motor Industry Development Programme (MIDP) - its objective is to increase the productivity and competitiveness of the motor industry by providing incentives for local content in exported products. The scheme can be accessed by motor vehicle assemblers and component manufacturers and exporters.

Innovation Fund - promote technological innovation within the research community and cross-sectoral collaboration. The fund can be used by companies who undertake research and development in the following areas (to be revised during 2004):

- Promotion of information and communication technology (ICT)

- Molecular-based biotechnology

- Value-added processes: fauna and flora

- Value-added processes: new materials and advanced manufacturing.

For more information, refer to www.thedti.gov.za

\section{References}

1 AMSDEN, A. (1997) "South Korea": in Enterprising Groups and Entrepreneurial Government, Chandler, A. et al. (eds.)

2 BERTRAND, D.; PHELE, T; ROBERTS, S.; STEUART, I. \& TAKA, M. (2004) "Western Cape report on metals \& engineering industries, including ship-building," study commissioned by the Western Cape Provincial Government.

3 BEST, M. (2001) The New Competitive Advantage, Oxford University Press: Oxford.

4 CHANDLER, A.; AMATORI, F \& HIKINO, T (eds.) (1997) Big Business and the Wealth of Nations, Cambridge University Press: Cambridge.

5 CHANDLER, A. (1990) Scale and Scope: The Dynamics of Industrial Capitalism, Harvard University Press: Cambridge, MA.

6 DEPARTMENT OF SCIENCE AND TECHNOLOGY (DST) (2002) South Africa's National Research and Development Strategy.

7 DEPARTMENT OF TRADE AND INDUSTRY (DTI) (2002) Accelerating Growth and Development: The Contribution of the Integrated Manufacturing Strategy.

8 DOBREVA, R. \& MADOSI, L. (2004) "The plastic products sector in Ekurhuleni”, Ekurhuleni Briefing Paper 7, http:// www.wits.ac.za/sebs/csid/ekurhuleni.html

9 DOSI, G.; FREEMAN, C. \& FABIANI, S. (1994) "The process of economic development: Introducing some stylized facts and theories on technologies, firms and institutions", Industrial and Corporate Change, 3(1):1-45. 
10 DOSI, G.; TEECE, D.J. \& CHYTRY, J. eds. (1998) Technology, Organization, and Competitiveness - Perspectives on Industrial and Corporate Change, Oxford University Press: Oxford.

11 HELMSING, A.H.J. (2001) “, Learning and governance: New perspectives on local economic development", Development and Change, 32:277-308

12 KAPLAN, D. (1999) "On the literature of the economics of technical change: Science and technology policy in South Africa”, South African Journal of Economics, 67(4):473-490.

13 KAPLINSKY, R. (2000) "Globalisation and unequalisation: What can be learned from value chain analysis?", Journal of Development Studies, 37(2):117-146.

14 KRUGMAN, P. (1998a) "Space: the final frontier", Journal of Economic Perspectives, 12(2):161-174.

15 KRUGMAN, P. (1998b) "What's new about the new economic geography?", Oxford Review of Economic Policy, 14(2):7-17.

16 LALL, S. (2003) "Reinventing industrial strategy: The role of government policy in building industrial competitiveness", paper for the Intergovernmental Group on Monetary Affairs and Development (G24).

17 LALL, S. (1994) "The East Asian miracle study: Does the bell toll for industrial strategy?", World Development, 22(4):645-654.

18 LALL, S. \& TEUBAL, M. (1998) "Marketstimulating technology policies in developing countries: a framework with examples from East Asia”, World Development, 26(8):1369-1385.

19 MACHAKA, J. \& ROBERTS, S. (2003) "The DTI's new 'Integrated manufacturing strategy? Comparative industrial performance, linkages and technology", South African Journal of Economics, 70(4):679-704.

20 MACHAKA, J. \& ROBERTS, S. (2004a) "Addressing the apartheid industrial legacy: local economic development and industrial policy in South Africa - the case of Ekurhuleni", paper presented at Wits-Ekurhuleni Symposium on Sustainable Manufacturing, 10-11 June.

21 MACHAKA, J. \& ROBERTS, S. (2004b) "Manufacturing industry in Ekurhuleni: Analysis of recent performance and findings from firm survey," Ekurhuleni Briefing Paper 9, http:// www.wits.ac.za/sebs/csid/ekurhuleni.html

22 MASETHE, R. \& ROBERTS, S. (2003) "The metal products sector in Ekurhuleni," Ekurhuleni Briefing Paper 5, http://www.wits.ac.za/sebs/csid/ ekurhuleni.html

23 NATIONAL COUNCIL ON INNOVATION (NACI) (2003), Advanced Manufacturing Technology Strategy.

24 SCHMITZ, H. (1995) "Collective efficiency: growth path for small-scale industry", Journal of Development Studies, 31(4):529-566.

25 VILJOEN, H. (2003) "Foundry industry analysis: The growth potential in the Foundry Industry and recommendations on exploiting available opportunities", report commissioned by the South African Institute of Foundrymen, April 2003. 